\title{
The Importance Of A Consultation Liaison Psychiatry Service In General Hospitals: A Brazilian 6-Years Experience
}

Yoichi Takaki Konno ( $\square$ yoichi.konno@gmail.com )

FAMERP: Faculdade de Medicina de Sao Jose do Rio Preto https://orcid.org/0000-0001-8042-8530

\section{Fernanda Menezes de Faria}

FAMERP: Faculdade de Medicina de Sao Jose do Rio Preto

Gisele Zocoller Seno

FAMERP: Faculdade de Medicina de Sao Jose do Rio Preto

Vinicius dos Santos Sguerri

FAMERP: Faculdade de Medicina de Sao Jose do Rio Preto

Ana Carolina Gonçalves Olmos

FAMERP: Faculdade de Medicina de Sao Jose do Rio Preto

Marília Capuço Oliveira

FAMERP: Faculdade de Medicina de Sao Jose do Rio Preto

Celina Dias e Santos Lazzaro

FAMERP: Faculdade de Medicina de Sao Jose do Rio Preto

Gerardo Maria Araújo Filho

FAMERP: Faculdade de Medicina de Sao Jose do Rio Preto

\section{Primary research}

Keywords: consultation liaison, psychiatry, general hospital, psychiatric disorders in general hospital

Posted Date: April 20th, 2021

DOI: https://doi.org/10.21203/rs.3.rs-435538/v1

License: (c) (1) This work is licensed under a Creative Commons Attribution 4.0 International License. Read Full License 


\section{Abstract}

Background: The importance of consultation-liaison psychiatry (CLP) services have been progressively growing in all general hospitals.

Methods: Data were collected from medical records of patients treated by the CLP service, from 2014 to 2020, including clinicaldemographic data, characteristics of hospitalization, reason for request, treatment plan, and clinical outcome. For these analyses, the chi-square test, z-test, and Kruskal-Wallis test were used. The level of significance was set at $5 \%$.

Results: A total of 2,742 consultation requests were evaluated by the psychiatry team. The number of requests made grew by $109.64 \%$ over the years. In $58.21 \%$ of cases, the patient was in the ward, and $33 \%$ were requested by Internal Medicine. There was a statistically significant difference $(p<0.001)$ in the distribution of reasons for request according to patients' characterization variables.

Conclusions: This study sought to analyze the functioning and growth of CLP in a tertiary Brazilian general hospital. The present findings reinforce the importance of this service and the need to implement and develop CLP in general hospitals.

\section{Highlights}

- The importance of CLP services have been growing in all general hospitals

- This study outlined the profile of a CLP service of a large tertiary Brazilian general hospital.

- The number of requests had grown by $109.64 \%$ in 4 years.

- The response time was shorter in the emergency area.

- Internal Medicine had the most requests for CLP service.

\section{Introduction}

The Consultation-Liaison Psychiatry (CLP) service was developed based on the need for interaction and integration of the mental health professionals with other medical specialists in the general hospital; in order to reduce the social stigma caused by the psychiatric disorders and improve the care for the psychiatric patients based on the biopsychosocial model [1-4]. Past research has already observed that CLP services are cost-effective as they decrease the length of hospitalization stay [5-7]. In addition, CLP services expand the detection and interventions on psychiatric comorbidities, with a good acceptability by patients [6]. In addition, considering the CLP service as an area of increasing importance in the rearrangement of mental health services, it is essential that their demand, service profile, and patients' characteristics can be taken in account, in order to detect obstacles and limitations of the service, as well as improve the cost-benefit ratio of clinical hospitalizations. Based on these premises, the aim of this study was to outline the profile of a CLP service of a large tertiary Brazilian general hospital.

\section{Materials And Methods}

The present investigation is an observational, cross-sectional, retrospective and descriptive study of the CLP service at a tertiary care university-affiliated teaching hospital, Hospital de Base, located in the city of Sao Jose do Rio Preto, Brazil. The Hospital de Base, located in the city of Sao Jose do Rio Preto and connected to the FAMERP, is one of the largest teaching hospitals in Brazil, with 146,467 visits/year, 89,754 attendances in emergency, and 41,226 hospitalizations. The hospital has a CLP service with expertise in psychiatric consulting and production of scientific articles [8].

All data were collected retrospectively from 2,742 inpatient consultation requests from medical records using a structured form (Google Forms). The collection was made independently through the data obtained from the consultants' requests and responses. This study was approved by the Research Ethics Committee of the Faculdade de Medicina de Sao Jose do Rio Preto (FAMERP number 36147620.0.0000.5415).

\subsection{Statistical analysis}


The variables analyzed were number of requests for the CLP service; hospital process variables (lag time, length and number of hospitalizations), sociodemographic profile, clinical and psychiatric diagnosis (reason for requesting, previous psychiatric history, previous/diagnosis/hospitalization, and psychiatric family history), interventions (pharmacological and non-pharmacological treatment plan, prescribed drugs, reassessment and non-evaluation).

Statistical analyses were performed using SPSS 20 software. For descriptive analyses, the chi-square test was used; and z-test was used to compare the proportions of the columns. The Kruskal-Wallis test was used to compare the response time after a request for consultation between the main requesting areas (emergency, infirmary and ICU). The level of significance was set at $5 \%$.

\section{Results}

A total of 2,742 consultation requests for the CLP service were evaluated, which correspond to 0.73 to $1.50 \%$ of the total hospital admissions in the period. The number of CLP requests grew by $109.64 \%$ in the period of the study (Figure 1). Regarding patients' sociodemographic characteristics, $1,516(55 \%)$ were female, the mean age was $43.22 \pm 18.00$ years and the median age was 43.00 years; 908 (33.2\%) had not completed elementary school, 1,015 (37.5\%) were married or in a stable relationship; 762 (27.8\%) were Catholic, 1,850 (67.47\%) were living with a family member; and 1,725 (62.6\%) did not work due to retirement $(n=479,26.9 \%)$, unemployment $(n=410,23 \%)$, due to health conditions $(n=244,12.9 \%)$, or being a "housewife" $(n=173,9.7 \%)$. The majority $(73.60 \%)$ had a psychiatric history, $55.43 \%$ had a previous psychiatric diagnosis, $29.54 \%$ had a psychiatric follow-up, $22.25 \%$ had a previous psychiatric hospitalization, and $52 \%$ had a family psychiatric history.

Requests for CLP service were made $8.20 \pm 20.60$ days after the patient's admission, and the team's responses were provided after $9.65 \pm 21.85$ days. The response time between the request and response was of $1.43 \pm 4.36$ days. Regarding the evaluation site, $1,596(58.21 \%)$ patients were in the ward, $949(34.61 \%)$ in the emergency room, $182(6.64 \%)$ in the ICU, $3(0.11 \%)$ in the operating room, $2(0.07 \%)$ in the ambulatory room, $1(0.04 \%)$ unavailable, $7(0.26 \%)$ not informed, and $2(0.07 \%)$ in other situations. Most consultations ( $n=901,32.5 \%)$ were requested by Internal Medicine. The main reasons for requesting CLP evaluation were: a) presence of a previous psychiatric disorder; b) use of psychiatric medication; c) presence of ill-defined symptoms; and d) history of suicide attempts. Reassessments were necessary for 415 patients (16\%), and the CLP service did not evaluate 196 patients (7.2\%) because of reasons such as discharge, inability to answer correctly, coma/intubation, evasion, and death.

Among the pharmacological treatment plans, the introduction of psychotropic drugs was the most commonly performed procedure, occurring in 894 patients (30.86\%). The most frequently prescribed classes of drugs were, in order, antidepressants, antipsychotics, and benzodiazepines. In addition, outpatient follow-up was the CLP service's most frequent recommendation to continue the treatment, followed by being admitted to a general hospital, referral to a psychiatric emergency, and referral to one of the services of the publicly psychiatric care network.

There was a statistically significant difference in the distribution of the reasons for CLP evaluation according to the patients' characterization variables: gender $(p \leq 0.001)$, city $(p=0.018)$, presence of a companion during hospitalization $(p \leq 0.001)$, age $(p \leq 0.001)$, and marital status ( $p \leq 0.001)$, as shown in Tables 1 and 2 . Considering the three main hospital scenarios (emergency, infirmary, and ICU) that requested consultation, the response time was shorter for the emergency $(0.92 \pm 0.83)$, and comparable for the infirmary department $(1.46 \pm 1.17)$ and ICU $(1.53 \pm 1.24)(p<0.001)$.

There was a statistically significant difference when the consultations were not performed, and the ICU presented a higher number of non-assessments $(p \leq 0.001)$. Regarding the reasons for non-evaluation, it is noteworthy that "Hospital discharge" was less common in the ICU, "Absence due to laboratory test/procedures" was less common in the Emergency department and more common in the Infirmary department, "Evasion" was more common in the Emergency department, and "Impossibility to respond (coma, intubation)" was more common in the ICU ( $\mathrm{s} \leq 0.001)$. The reason for not evaluating due to "Inability to respond correctly" and the other reasons were not associated with the requesting department (Table 3).

\section{Discussion}


Since its introduction in Brazil in 1977, the CLP service has been the link between patients, family, medical staff, and external health services in the field of mental health. In many cases, it is also the first opportunity for psychiatric care, further emphasizing the importance of this service $[3,9,10,11]$. CLP services are present in $86 \%$ of general hospitals, with the vast majority in university hospitals [9, 12-14]. To the best of our knowledge, this is one of the largest studies on Brazilian CLP services, which involved an elevated number of requests $(2,742)$, and with a large time interval (six years).

The number of CLP requests corresponded to 0.73 to $1.50 \%$ of the total hospital admissions in the period. Studies with different follow-up periods have disclosed that CLP requests correspond to $0.9-2 \%$ of all hospital admissions [13-22]. Despite the similarity to literature, this frequency remains below what is expected from the prevalence of mental disorders in Brazil $[21,23]$. One reason for this discrepancy is probably the passive screening by the CLP teams [24].

The sociodemographic characteristics observed in this study agreed with other published reports in the field [15-31]. Similarly to other long-term studies, the geriatric population corresponded to almost $10 \%$ of the sample $[15,16]$. Another study conducted at the Hospital de Base of Sao Jose do Rio Preto from 2010 to 2014 showed that $14.33 \%$ of the consultations were made for elderly patients, which is the same proportion as our data [32]. In contrast, Bambarén [25] found $41.6 \%$ total psychiatric consultations for the elderly population in Rio Grande do Sul, Brazil and Wancata [33], with 45.3\% in a hospital in Vienna, Austria. The difficulty in managing these patients, since they may have greater morbidity, comorbidities, and drug interactions, may be obstacles to psychiatric consultation in the coming years.

The CLP response time was in agreement with other studies, with a large portion being answered before 48h [16]. In this study, a faster response was observed for the Emergency sector, due to the serious nature of the cases $(p<0.001)$. In addition, the time between admission and request for consultation (lag time) was also consistent with other studies, varying between 3 and 15 days $[13,15,19]$. In a study by Nakabayashi [19], endocrine, metabolic, and nutritional conditions were observed and early consultations were requested, due to dysfunctional conditions that required rapid intervention. In cases where there was no possibility of evaluation, it was observed in this study that such cases occurred in the ICU $(p<0.001)$. As the main change was "intubation", a better communication between the teams seems to be essential. Such data have not been frequently related in other studies in this field; this sheds light on this very common occurrence in general hospitals.

Regarding the frequency of the teams that requested CLP evaluation, Internal Medicine has been the most frequent $[13,15,16,19$, $21,28-30]$. This finding would be associated with the possible greater sensitivity and accuracy of clinicians in detecting behavioral alterations. Furthermore, according to Kishi et al. [29], clinical physicians have higher measures of empathy than those in specialties focused on technology, such as anesthesiology, surgery, and other surgical subspecialties, which may explain the reason for delays or lower demands on surgical wards.In addition, the infirmary was the location of more than half of the cases of CLP requests. This finding was discordant to what has been found in other studies; Huyse [34] observed that the emergency corresponded to $33 \%$ of the service, mainly due to suicide attempts, self-mutilation, and intoxication by psychoactive substances $[33,34]$.

Regarding psychiatric diagnoses, in a study by Magdaleno et al [18], the main diagnoses were adjustment disorder (24.6\%), depression (23\%) and organic psychotic conditions (18.8\%). In another Brazilian research, the psychiatric disorders were depression, adjustment and personality disorders [19]. A 30-years study by Nakabayashi (2012) showed mood disorder (40.4\%), neurotic disorders (13.8\%), substance use disorders (12.8\%) [16]. At the international level, in a collaborative study of 56 services from 11 European countries, the main causes of solicitation were self-mutilation (17\%), substance abuse (7.2\%), current psychiatric symptoms (38.6\%) and unexplained physical complaints (18.6\%) [13]. Bellomo et al. [35] observed that mood disorders (most common) occurred in 10-50\%, adjustment disorder in 3-19\%, and anxiety disorders in $0-18 \%$ of patients $[10,13,17,18,19,20$, $21,28,31]$. However, other diagnoses are also important. Regarding substance use disorders, despite its importance and elevated frequency of diagnoses, it is still much lower than the overall prevalence in Brazil; as in other studies, it shows that the treatment is focused on acute conditions (intoxications and abstinence), and not so much for the dependence itself $[13,36]$.

As for the therapeutic plan, the majority have focused on drug treatment, as well as other research [16]. Antidepressants have been selected in most cases in several studies [21, 25, 32]. After discharge, the patient was referred to a service for follow-up if necessary. In a study by Rigatelli [10], psychiatric outpatient clinics were the main destination (29\%), followed by primary care units (27\%), private practices (8\%), and maintenance of hospitalization (6\%). 
Most studies in the field of CLP seek to show the cost savings of this type of service, but there are important methodological flaws, the impossibility of building an adequate control group, short follow-up time, absence of prospective data, and standardized documentation $[9,15,37]$. This absence of quality indicators conveys the erroneous feeling that the CLP service does not produce anything or does not have concrete goals [38]. Therefore, as long as randomized clinical trials are not carried out, it is important to complement them with retrospective/prospective studies to record the evolution and development of the CLP service [16, 39]. Moreover, due to the low percentage of requests compared with total hospital admissions, the CLP has been mostly seen as a reactive measure by general hospitals to obtain emergency psychiatric care, rather than as a mental health strategy. Therefore, CLP services often suffer from exclusive issues such as stigma, financial disincentives, lack of an adequate multidisciplinary team, or low remuneration [38, 40-42]. This is reflected in the high turnover of the CLP team, often with a short experience and less production of research data $[13,27,43,44]$.

The present study has several limitations. Despite being a relatively long-term study, as it is transversal and retrospective, it does not reflect the national reality. Different hospital configurations, consultants, study periods, sample sizes, and diagnostic classification systems can cause heterogeneity with other services. Standardized psychiatric scales and structured clinical interviews were not used in this study. Due to the methodology, the patients' hospitalization time and other interesting data, such as adherence by the team, were not obtained.

\section{Conclusion}

The present study with an elevated number of CLP requests $(2,742)$ and with a large time interval (six years) observed several similarities with other Brazilian and international services. The findings of this research reinforce the importance of this service and the need to implement and develop CLP in general hospitals. Training and hiring of a multidisciplinary team, 24/7 availability, investment in scientific updating, creation of protocols, and coordination with other specialties with internal flowcharts are essential to improve the quality of CLP teams, and consequently the quality of patients' psychiatric care in general hospitals.

\section{Abbreviations}

CLP = Consultation Liaison Psychiatry

FAMERP $=$ Faculdade de Sao Jose do Rio Preto

$\mathrm{ICU}=$ Intensive Care Unit

GAD = Generalized Anxiety Disorder

\section{Declarations}

\section{Ethics approval and consent to participate}

Not applicable.

\section{Consent for publication}

Not applicable.

Availability of data and materials

Not applicable.

\section{Competing interests}

All the authors work at Hospital de Base and Faculdade de Medicina de Sao Jose do Rio Preto.

\section{Funding}


This research did not receive any specific grant from funding agencies in the public, commercial, or not-for-profit sectors.

\section{Authors' contributions}

YK, FF, GS, VS analyzed and interpreted the collected data. YK, AO, MO, CL, GF were responsible for writing and review the manuscript. All authors read and approved the final manuscript

\section{Acknowlegments}

The authors thank Prof. Dr. Neury José Botega for advice, and Dr. Fernanda Salloume Sampaio

\section{References}

1. Botega JN. Prática psiquiátrica no hospital geral: interconsulta e emergência - 4. ed. Porto Alegre: Artmed; 2017.

2. Hopkins J, Cullum S, Sundram F. The state of play - the first national survey of consultation-liaison psychiatry services in New Zealand. Australas Psychiatry. 2020;1039856220908174. doi:10.1177/1039856220908174.

3. Luna JVA. Aventuras da Psiquiatria no Hospital Geral: Aspectos históricos da interconsulta na UFPE e no HBL. Master thesis. Universidade Federal de Pernambuco. 2016; $105 \mathrm{f}$. https://repositorio.ufpe.br/bitstream/123456789/17835/1/Disserta\%C3\%A7\%C3\%A3o_Juliano_Biblioteca.pdf.

4. Zipfel S, Herzog W, Kruse J, Henningsen P. Psychosomatic Medicine in Germany: More Timely than Ever. Psychother Psychosom. 2016;85(5):262-9. doi:10.1159/000447701.

5. Vulser $\mathrm{H}$, Vinant $\mathrm{V}$, Lanvin $\mathrm{V}$, et al. Association between the timing of consultation-liaison psychiatry interventions and the length of stay in general hospital [published online ahead of print, 2019 Nov 13]. Br J Psychiatry. 2019;1-6. doi:10.1192/bjp.2019.233.

6. Wood R, Wand AP. The effectiveness of consultation-liaison psychiatry in the general hospital setting: a systematic review. J Psychosom Res. 2014;76(3):175-92. doi:10.1016/j.jpsychores.2014.01.002.

7. Wood R, Wand AP, Hunt GE. Relationship between timeliness of contact and length of stay in older and younger patients of a consultation-liaison psychiatry service. BJPsych Bull. 2015;39(3):128-33. doi:10.1192/pb.bp.114.047340.

8. Hospital de Base. 2020. website: https://www.hospitaldebase.com.br/hb-em-numeros.

9. Nogueira-Martins LA, Botega NJ. Interconsulta psiquiátrica no Brasil: desenvolvimentos recentes. Revista ABP-APAL. 1998;20(3):105-11.

10. Rigatelli M, Casolari L, Massari I, et al. A follow-up study of psychiatric consultations in the general hospital: What ha-pens to patients after discharge? Psychother Psychosom. 2001;70(5):276-82. doi:10.1159/000056266.

11. Wise TN. Update on consultation-liaison psychiatry (psychosomatic medicine). Curr Opin Psychiatry. 2008;21(2):196-200. doi:10.1097/YCo.0b013e3282f393ae.

12. Silva NG, Oliveira A. Interconsulta psiquiátrica e unidades de internação psiquiátrica no Brasil: uma pesquisa bibliográfica. 0 Mundo da Saúde. 2010;35:244-51. doi:10.15343/0104-7809.2010244251.

13. Huyse FJ, Herzog T, Lobo A, et al. Consultation-Liaison psychiatric service delivery: results from a European study. Gen Hosp Psychiatry. 2001;23(3):124-32. doi:10.1016/s0163-8343(01)00139-6.

14. Rymaszewska J, Söllner W. Training in consultation-liaison psychiatry in Eastern Europe. J Psychosom Res. 2012;72(6):4602. doi:10.1016/j.jpsychores.2012.02.006.

15. Diefenbacher A, Strain JJ. Consultation-liaison psychiatry: stability and change over a 10-year-period. Gen Hosp Psychiatry. 2002;24(4):249-56. doi:10.1016/s0163-8343(02)00182-2.

16. Nakabayashi TIK. Caracterização do padrão de solicitações Psiquiátricas em um hospital geral: estabilidade e mudança em um período de 30 anos de um serviço de interconsulta. Tesis doctoral. Faculdade de Medicina de Ribeirão Preto da Universidade de São Paulo. 2012; 214 f. http://pgsm.fmrp.usp.br/wp-content/uploads/2014/11/DOUTORADO-Tatiana-lurikoKawasaki-Nakabayashi.pdf. 
17. Hengeveld MW, Rooymans HG, Vechtvan den Bergh R. Psychiatric consultations in a Dutch university hospital: a report on 1814 referrals, compared with a literature review. Gen Hosp Psychiatry. 1984;6(4):271-9. doi:10.1016/0163-8343(84)90021-5.

18. Magdaleno JR Jr, Botega JN. Interconsulta psiquiátrica no Hospital Geral Universitário: um ano no Hospital das Clínicas/ UNICAMP. Jornal Brasileiro de Psiquiatria. 1991;40(2):95-8.

19. Nakabayashi TIK, Guerra KA, Souza RM, et al. Comparação entre solicitações psiquiátricas de dois hospitais gerais universitários brasileiros: uso do protocolo de registro de interconsulta em saúde mental. Cadernos de Saúde Pública. 2010;26(6):1246-60. doi:10.1590/S0102-311X2010000600017.

20. Smaira SI, Kerr-Corrêa F, Contel JOB. Psychiatric disorders and psychiatric consultation in a general hospital: a case- control study. Brazilian Journal of Psychiatry. 2003;25(1):18-25. https://doi.org/10.1590/S1516-44462003000100005.

21. Su JA, Chou SY, Chang CJ, Weng HH. Changes in consultation-liaison psychiatry in the first five years of operation of a newlyopened hospital. Chang Gung Med J. 2010;33(3):292-300.

22. Wallen J, Pincus HA, Goldman HH, Marcus SE. Psychiatric consultations in short-term general hospitals. Arch Gen Psychiatry. 1987;44(2):163-8. doi:10.1001/archpsyc.1987.01800140073010.

23. Rothenhäusler HB, Stepan A, Kreiner B, Baranyi A, Kapfhammer HP. Patterns of psychiatric consultation in an Austrian tertiary care center - results of a systematic analysis of 3,307 referrals over 2 years. Psychiatr Danub. 2008;20(3):301-9.

24. Leentjens AF, Boenink AD, Sno HN, et al. The guideline "consultation psychiatry" of the Netherlands Psychiatric Association. J Psychosom Res. 2009;66(6):531-5. doi:10.1016/j.jpsychores.2009.03.001.

25. Bambarén $\mathrm{CY}$, Zimmermann PR, Sfoggia A. Characteristics of requests for psychiatric consultation-liaison in elderly hospitalized in a university hospital in southern of Brazil. PAJAR, Pan Am. J. Aging Res. 2015;3(1):8-14. https://revistaseletronicas.pucrs.br/ojs/index.php/pajar/article/view/19739.

26. Christodoulou C, Fineti K, Douzenis A, Moussas G, Michopoulos I, Lykouras L. Transfers to psychiatry through the consultation-liaison psychiatry service: 11 years of experience. Ann Gen Psychiatry. 2008;7:10. doi:10.1186/1744-859X-7-10.

27. De Giorgio G, Quartesan R, Sciarma T, et al. Consultation-Liaison Psychiatry-from theory to clinical practice: an observational study in a general hospital. BMC Res Notes. 2015;8:475. doi:10.1186/s13104-015-1375-6.

28. Devasagayam D, Clarke D. Changes to inpatient consultation-liaison psychiatry service delivery over a 7-year period. Australas Psychiatry. 2008;16(6):418-22. doi:10.1080/10398560802074676.

29. Kishi Y, Meller WH, Kathol RG, Swigart SE. Factors affecting the relationship between the timing of psychiatric consultation and general hospital length of stay. Psychosomatics. 2004;45(6):470-6. doi:10.1176/appi.psy.45.6.470.

30. Pardiñas SMG. Interconsulta Psiquiátrica en un Hospital General Intentos de Suicidio y Factores Relacionados (1997-2007). Tesis Doctoral. Universidade da Coruña. 2013; $131 \mathrm{f}$. https://ruc.udc.es/dspace/bitstream/handle/2183/10135/GomezPardinas_SoniaMaria_TD_2013.pdf? sequence $=5$ \&isAllowed $=y$.

31. Porcellana R, Panariello A, Percudani M. Consultation-Liaison Psychiatry for Outpatients in a Great Metropolitan Hospital. Journal of Psychology Research 2019; 9. doi:10.17265/2159-5542/2019.01.001.

32. Ribeiro AESA. Caracterização clínica e sócio-demográfica dos pacientes idosos internados em hospital terciário e avaliados pelo serviço de interconsulta psiquiátrica. Master thesis. Faculdade de Medicina de São José do Rio Preto. 2018; 64 f. http://bdtd.famerp.br/bitstream/tede/467/2/AnaElisaS\%c3\%a1AntunesRibeiro_dissert.pdf.

33. Wancata J, Windhaber J, Bach M, Meise U. Recognition of psychiatric disorders in nonpsychiatric hospital wards. J Psychosom Res. 2000;48(2):149-55. doi:10.1016/s0022-3999(99)00098-7.

34. Huyse FJ, Herzog T, Lobo A, et al. European consultation-liaison services and their user populations: the European Consultation-Liaison Workgroup Collaborative Study. Psychosomatics. 2000;41(4):330-8. doi:10.1176/appi.psy.41.4.330.

35. Bellomo A, Altamura M, Ventriglio A, Rella A, Quartesan R, Elisei S. Psychological factors affecting medical conditions in consultation-liaison psychiatry. Adv Psychosom Med. 2007;28:127-40. doi:10.1159/0000106801.

36. Simpson SA, Chwastiak LA, Andrews SR, et al. Updates in Consultation-Liaison Psychiatry: 2019. Psychosomatics. 2020;61(5):450-5. doi:10.1016/j.psym.2020.05.001. 
37. Citero VA, Andreoli PBA, Nogueira-Martins LA, Andreoli SB. Por que é tão difícil avaliar a efetividade da interconsulta psiquiátrica? Brazilian Journal of Psychiatry. 2002;24(2):100. doi:10.1590/S1516-44462002000200012.

38. Goldberg RJ, Burock J, Harrington CJ. Quality indicators in consultation-liaison psychiatry. Psychosomatics. 2009;50(5):550. doi:10.1176/appi.psy.50.5.550.

39. Smith GC. From consultation-liaison psychiatry to integrated care for multiple and complex needs. Aust N Z J Psychiatry. 2009;43(1):1-12. doi:10.1080/00048670802534358.

40. Ajiboye PO. Consultation-liaison psychiatry: the past and the present. Afr J Med Med Sci. 2007;36(3):201-5.

41. Fabrissin J. La interconsulta y las actividades de enlace en el Hospital General: estrategias para su efectividad. Vertex Rev Arg de Psiquiat. 2011;XXII:356-67.

42. Strain JJ, Blumenfield M. Challenges for consultation-liaison psychiatry in the 21st century. Psychosomatics. 2008;49(2):936. doi:10.1176/appi.psy.49.2.93.

43. Botega JN, Guilhermano LG, Michel R, et al. Consultoria psiquiátrica em hospital geral: inviável ou promissora? Brazilian Journal of Psychiatry. 2000;22(3):130-2. doi:10.1590/S1516-44462000000300006.

44. Söllner W, Creed F, European Association of Consultation-Liaison Psychiatry and Psychosomatics Workgroup on Training in Consultation-Liaison. European guidelines for training in consultation-liaison psychiatry and psychosomatics: report of the EACLPP Workgroup on Training in Consultation-Liaison Psychiatry and Psychosomatics. J Psychosom Res. 2007;62(4):5019. doi:10.1016/j.jpsychores.2006.11.003.

\section{Tables}

Table 1. Study of the association between the reason for evaluation and patient profile. 


\begin{tabular}{|c|c|c|c|c|c|c|c|c|c|c|c|c|}
\hline \multirow[b]{2}{*}{$\begin{array}{l}\text { Reason for } \\
\text { evaluation }\end{array}$} & \multicolumn{2}{|l|}{ Gender } & \multicolumn{2}{|l|}{ City } & \multicolumn{2}{|l|}{ Work } & \multicolumn{2}{|c|}{ Companion } & \multicolumn{2}{|l|}{ Age } & \multicolumn{2}{|c|}{ Marital status } \\
\hline & Woman & Man & Other & SJRP & No & Yes & No & Yes & $<43$ & $\geq 43$ & Other & Married \\
\hline $\begin{array}{l}\text { Previous } \\
\text { psychiatric } \\
\text { patients and / or } \\
\text { used psychiatric } \\
\text { medication }\end{array}$ & $498^{a}$ & $282^{b}$ & $517^{\mathrm{a}}$ & $263^{a}$ & $548^{a}$ & $120^{\mathrm{b}}$ & $216^{a}$ & $509^{b}$ & $328^{a}$ & $448^{b}$ & $404^{a}$ & $260^{b}$ \\
\hline $\begin{array}{l}\text { Ill-defined } \\
\text { psychiatric } \\
\text { symptoms }\end{array}$ & $433^{a}$ & $246^{\mathrm{b}}$ & $444^{a}$ & $235^{a}$ & $460^{\mathrm{a}}$ & $143^{b}$ & $233^{a}$ & $387^{b}$ & $315^{a}$ & $362^{a}$ & $293^{a}$ & $302^{b}$ \\
\hline Suicide attempt & $282^{a}$ & $205^{a}$ & $288^{a}$ & $199^{b}$ & $265^{a}$ & $169^{b}$ & $155^{a}$ & $286^{a}$ & $338^{a}$ & $149^{b}$ & $255^{a}$ & $162^{b}$ \\
\hline $\begin{array}{l}\text { Substance } \\
\text { use/abuse }\end{array}$ & $70^{a}$ & $259^{b}$ & $195^{a}$ & $134^{\mathrm{b}}$ & $175^{a}$ & $102^{b}$ & $131^{a}$ & $163^{\mathrm{b}}$ & $170^{\mathrm{a}}$ & $158^{a}$ & $184^{a}$ & $90^{\mathrm{b}}$ \\
\hline Suicide risk & $158^{a}$ & $99^{b}$ & $158^{\mathrm{a}}$ & $99^{a}$ & $146^{a}$ & $75^{b}$ & $80^{a}$ & $144^{a}$ & $144^{a}$ & $111^{\mathrm{b}}$ & $124^{\mathrm{a}}$ & $97^{a}$ \\
\hline $\begin{array}{l}\text { General } \\
\text { psychiatric } \\
\text { evaluation }\end{array}$ & $124^{\mathrm{a}}$ & $108^{a}$ & $161^{a}$ & $71^{a}$ & $148^{\mathrm{a}}$ & $59^{a}$ & $67^{a}$ & $143^{a}$ & $102^{a}$ & $126^{a}$ & $102^{\mathrm{a}}$ & $103^{a}$ \\
\hline $\begin{array}{l}\text { Psychomotor } \\
\text { agitation }\end{array}$ & $70^{a}$ & $116^{\mathrm{b}}$ & $122^{a}$ & $64^{a}$ & $118^{\mathrm{a}}$ & $30^{b}$ & $44^{a}$ & $133^{b}$ & $70^{a}$ & $116^{\mathrm{b}}$ & $99^{a}$ & $53^{b}$ \\
\hline $\begin{array}{l}\text { Acute behavioral } \\
\text { change (delirium) }\end{array}$ & $90^{\mathrm{a}}$ & $79^{a}$ & $115^{a}$ & $54^{a}$ & $125^{\mathrm{a}}$ & $22^{b}$ & $23^{a}$ & $130^{\mathrm{b}}$ & $23^{a}$ & $146^{\mathrm{b}}$ & $70^{a}$ & $64^{a}$ \\
\hline $\begin{array}{l}\text { Psychosomatic/ill- } \\
\text { defined physical } \\
\text { symptoms }\end{array}$ & $114^{\mathrm{a}}$ & $40^{\mathrm{b}}$ & $106^{a}$ & $48^{a}$ & $81^{a}$ & $60^{b}$ & $32^{a}$ & $113^{\mathrm{b}}$ & $96^{a}$ & $58^{b}$ & $54^{a}$ & $77^{b}$ \\
\hline $\begin{array}{l}\text { Withdrawal } \\
\text { symptoms }\end{array}$ & $22^{\mathrm{a}}$ & $122^{b}$ & $94^{a}$ & $50^{a}$ & $83^{a}$ & $49^{b}$ & $47^{a}$ & $85^{a}$ & $55^{a}$ & $89^{b}$ & $80^{a}$ & $40^{\mathrm{b}}$ \\
\hline $\begin{array}{l}\text { Difficulty in } \\
\text { accepting disease }\end{array}$ & $70^{a}$ & $62^{\mathrm{a}}$ & $94^{a}$ & $38^{a}$ & $88^{a}$ & $30^{\mathrm{a}}$ & $50^{a}$ & $69^{b}$ & $64^{a}$ & $68^{a}$ & $52^{a}$ & $68^{b}$ \\
\hline $\begin{array}{l}\text { Difficulty of the } \\
\text { team to cope } \\
\text { during } \\
\text { hospitalization }\end{array}$ & $66^{a}$ & $63^{a}$ & $85^{a}$ & $44^{a}$ & $82^{\mathrm{a}}$ & $24^{\mathrm{a}}$ & $36^{a}$ & $80^{a}$ & $64^{a}$ & $62^{a}$ & $61^{a}$ & $49^{a}$ \\
\hline $\begin{array}{l}\text { Exclusion of } \\
\text { organic cause }\end{array}$ & $37^{a}$ & $21^{a}$ & $42^{a}$ & $16^{a}$ & $38^{\mathrm{a}}$ & $17^{\mathrm{a}}$ & $17^{a}$ & $37^{a}$ & $30^{a}$ & $28^{a}$ & $26^{a}$ & $26^{a}$ \\
\hline $\begin{array}{l}\text { Difficulty in } \\
\text { bonding with the } \\
\text { newborn }\end{array}$ & $12^{\mathrm{a}}$ & $1^{\mathrm{b}}$ & $11^{a}$ & $2^{a}$ & $5^{a}$ & $4^{a}$ & $7^{a}$ & $3^{b}$ & $11^{\mathrm{a}}$ & $0^{b}$ & $1^{a}$ & $10^{\mathrm{b}}$ \\
\hline $\begin{array}{l}\text { Preoperative } \\
\text { evaluation }\end{array}$ & $7^{a}$ & $5^{a}$ & $11^{a}$ & $1^{a}$ & $8^{a}$ & $2^{a}$ & $3^{a}$ & $8^{a}$ & $5^{a}$ & $7^{a}$ & $6^{a}$ & $4^{\mathrm{a}}$ \\
\hline $\begin{array}{l}\text { Others (family } \\
\text { assessment, } \\
\text { physical abuse, } \\
\text { social risk) }\end{array}$ & $10^{a}$ & $4^{a}$ & $11^{a}$ & $3^{a}$ & $4^{a}$ & $3^{a}$ & $2^{\mathrm{a}}$ & $8^{a}$ & $7^{a}$ & $6^{a}$ & $4^{a}$ & $5^{a}$ \\
\hline Total & 2063 & 1712 & 2454 & 1321 & 2374 & 909 & 1143 & 2298 & 1822 & 1934 & 1815 & 1410 \\
\hline$X^{2}$ & 351,391 & & 28,573 & & 121,3 & & 76,114 & & 229,2 & & 80,952 & \\
\hline$p$ & $\leq 0.001 *$ & & $0.018^{*}$ & & $\leq 0.00$ & & $\leq 0.00$ & & $\leq 0.00$ & & $\leq 0.00$ & \\
\hline
\end{tabular}

* Statistically significant difference at a significance level of $5 \%$.

a,b Different letters denote a statistically significant difference. 
Table 2. Study of the association between psychiatric diagnosis and patient profile.

Page 10/13 


\begin{tabular}{|c|c|c|c|c|c|c|c|c|c|c|c|c|}
\hline & Gender & & City & & Work & & Comp & nion & Age & & Marita & status \\
\hline $\begin{array}{l}\text { Psychiatric } \\
\text { diagnosis }\end{array}$ & Woman & Man & Other & SJRP & No & Yes & No & Yes & $<43$ & $\geq 43$ & Other & Married \\
\hline Depression & $475^{a}$ & $210^{\mathrm{b}}$ & $438^{a}$ & $247^{a}$ & $462^{\mathrm{a}}$ & $170^{a}$ & $237^{a}$ & $398^{b}$ & $295^{a}$ & $388^{b}$ & $344^{\mathrm{a}}$ & $280^{a}$ \\
\hline $\begin{array}{l}\text { Adjustment } \\
\text { disorder }\end{array}$ & $214^{a}$ & $165^{\mathrm{a}}$ & $254^{\mathrm{a}}$ & $125^{\mathrm{a}}$ & $238^{a}$ & $117^{\mathrm{b}}$ & $128^{a}$ & $232^{\mathrm{a}}$ & $222^{\mathrm{a}}$ & $155^{b}$ & $157^{a}$ & $180^{\mathrm{b}}$ \\
\hline Delirium & $190^{\mathrm{a}}$ & $177^{a}$ & $253^{a}$ & $114^{\mathrm{b}}$ & $271^{a}$ & $59^{b}$ & $64^{a}$ & $294^{b}$ & $61^{a}$ & $306^{\mathrm{b}}$ & $181^{a}$ & $139^{a}$ \\
\hline $\begin{array}{l}\text { Alcohol related } \\
\text { disorder }\end{array}$ & $60^{\mathrm{a}}$ & $265^{\mathrm{b}}$ & $218^{a}$ & $107^{a}$ & $193^{a}$ & $114^{\mathrm{b}}$ & $107^{a}$ & $201^{a}$ & $98^{a}$ & $227^{b}$ & $197^{a}$ & $106^{b}$ \\
\hline GAD & $177^{a}$ & $102^{b}$ & $185^{a}$ & $94^{a}$ & $162^{\mathrm{a}}$ & $97^{b}$ & $98^{a}$ & $157^{b}$ & $174^{a}$ & $105^{b}$ & $113^{a}$ & $135^{\mathrm{b}}$ \\
\hline $\begin{array}{l}\text { Multiple } \\
\text { substance related } \\
\text { disorder }\end{array}$ & $61^{a}$ & $157^{b}$ & $114^{\mathrm{a}}$ & $104^{b}$ & $126^{a}$ & $60^{a}$ & $98^{a}$ & $104^{b}$ & $157^{a}$ & $60^{\mathrm{b}}$ & $131^{\mathrm{a}}$ & $54^{\mathrm{b}}$ \\
\hline $\begin{array}{l}\text { Personality } \\
\text { disorder }\end{array}$ & $149^{a}$ & $52^{\mathrm{b}}$ & $106^{a}$ & $95^{b}$ & $138^{a}$ & $48^{a}$ & $61^{a}$ & $127^{a}$ & $146^{\mathrm{a}}$ & $54^{b}$ & $106^{a}$ & $74^{\mathrm{a}}$ \\
\hline Psychotic disorder & $66^{a}$ & $115^{\mathrm{b}}$ & $117^{a}$ & $64^{a}$ & $141^{\mathrm{a}}$ & $16^{b}$ & $32^{a}$ & $145^{\mathrm{b}}$ & $82^{a}$ & $99^{a}$ & $130^{a}$ & $26^{\mathrm{b}}$ \\
\hline Bipolar disorder & $128^{a}$ & $48^{\mathrm{b}}$ & $113^{a}$ & $63^{a}$ & $120^{a}$ & $36^{a}$ & $51^{a}$ & $119^{a}$ & $69^{a}$ & $107^{b}$ & $87^{a}$ & $66^{a}$ \\
\hline Organic causes & $77^{a}$ & $84^{a}$ & $107^{a}$ & $54^{a}$ & $119^{a}$ & $20^{b}$ & $31^{a}$ & $125^{\mathrm{b}}$ & $50^{\mathrm{a}}$ & $111^{b}$ & $86^{a}$ & $52^{\mathrm{a}}$ \\
\hline $\begin{array}{l}\text { Dissociative } \\
\text { disorder }\end{array}$ & $78^{a}$ & $32^{b}$ & $68^{a}$ & $42^{a}$ & $64^{a}$ & $36^{b}$ & $17^{a}$ & $87^{b}$ & $74^{\mathrm{a}}$ & $36^{b}$ & $37^{a}$ & $59^{b}$ \\
\hline $\begin{array}{l}\text { Psychiatric } \\
\text { evaluation }\end{array}$ & $55^{a}$ & $37^{a}$ & $69^{a}$ & $23^{b}$ & $57^{a}$ & $29^{a}$ & $28^{a}$ & $53^{a}$ & $49^{a}$ & $42^{a}$ & $34^{a}$ & $50^{\mathrm{b}}$ \\
\hline $\begin{array}{l}\text { Intellectual } \\
\text { disability }\end{array}$ & $46^{\mathrm{a}}$ & $43^{a}$ & $58^{a}$ & $31^{a}$ & $71^{a}$ & $6^{\mathrm{b}}$ & $16^{a}$ & $72^{\mathrm{b}}$ & $60^{\mathrm{a}}$ & $29^{b}$ & $55^{a}$ & $22^{\mathrm{b}}$ \\
\hline $\begin{array}{l}\text { Cocaine related } \\
\text { disorder }\end{array}$ & $25^{a}$ & $41^{\mathrm{b}}$ & $29^{a}$ & $37^{\mathrm{b}}$ & $33^{a}$ & $26^{b}$ & $30^{\mathrm{a}}$ & $32^{b}$ & $55^{\mathrm{a}}$ & $11^{\mathrm{b}}$ & $36^{a}$ & $26^{a}$ \\
\hline $\begin{array}{l}\text { Nicotine related } \\
\text { disorder }\end{array}$ & $22^{a}$ & $43^{b}$ & $39^{a}$ & $26^{a}$ & $47^{a}$ & $14^{a}$ & $21^{a}$ & $40^{\mathrm{a}}$ & $21^{a}$ & $44^{b}$ & $30^{a}$ & $32^{\mathrm{a}}$ \\
\hline Dementia & $23^{a}$ & $25^{a}$ & $34^{a}$ & $14^{a}$ & $44^{a}$ & $2^{b}$ & $8^{a}$ & $40^{\mathrm{b}}$ & $2^{a}$ & $46^{b}$ & $21^{a}$ & $24^{a}$ \\
\hline Mood disorders & $23^{a}$ & $18^{a}$ & $33^{a}$ & $8^{b}$ & $24^{a}$ & $13^{a}$ & $11^{a}$ & $24^{a}$ & $18^{a}$ & $23^{a}$ & $17^{a}$ & $22^{\mathrm{a}}$ \\
\hline $\begin{array}{l}\text { Cannabinoids } \\
\text { related disorder }\end{array}$ & $10^{\mathrm{a}}$ & $27^{b}$ & $13^{a}$ & $24^{b}$ & $23^{a}$ & $10^{a}$ & $12^{a}$ & $25^{\mathrm{a}}$ & $29^{a}$ & $8^{\mathrm{b}}$ & $26^{a}$ & $10^{\mathrm{a}}$ \\
\hline $\begin{array}{l}\text { Somatoform } \\
\text { disorder }\end{array}$ & $16^{\mathrm{a}}$ & $7^{a}$ & $13^{a}$ & $10^{a}$ & $9^{a}$ & $13^{\mathrm{b}}$ & $5^{a}$ & $18^{a}$ & $15^{\mathrm{a}}$ & $8^{a}$ & $11^{a}$ & $10^{\mathrm{a}}$ \\
\hline $\begin{array}{l}\text { Hypnotics related } \\
\text { disorder }\end{array}$ & $9^{a}$ & $11^{\mathrm{a}}$ & $12^{\mathrm{a}}$ & $8^{a}$ & $12^{\mathrm{a}}$ & $6^{a}$ & $3^{a}$ & $14^{\mathrm{a}}$ & $8^{a}$ & $12^{\mathrm{a}}$ & $11^{a}$ & $8^{a}$ \\
\hline Phobia & $16^{a}$ & $3^{b}$ & $13^{a}$ & $6^{a}$ & $11^{a}$ & $6^{a}$ & $5^{a}$ & $11^{\mathrm{a}}$ & $10^{\mathrm{a}}$ & $9^{a}$ & $6^{a}$ & $10^{\mathrm{a}}$ \\
\hline Impulse disorder & $12^{\mathrm{a}}$ & $7^{a}$ & $11^{a}$ & $8^{a}$ & $12^{a}$ & $6^{a}$ & $5^{a}$ & $10^{\mathrm{a}}$ & $15^{a}$ & $4^{b}$ & $9^{a}$ & $8^{a}$ \\
\hline $\begin{array}{l}\text { Other } \\
\text { psychoactives } \\
\text { substances }\end{array}$ & $6^{a}$ & $10^{\mathrm{a}}$ & $10^{\mathrm{a}}$ & $6^{a}$ & $12^{\mathrm{a}}$ & $2^{a}$ & $6^{a}$ & $8^{a}$ & $9^{a}$ & $7^{a}$ & $10^{a}$ & $4^{a}$ \\
\hline Eating disorder & $10^{\mathrm{a}}$ & $4^{a}$ & $10^{\mathrm{a}}$ & $4^{a}$ & $13^{a}$ & $1^{a}$ & $2^{a}$ & $11^{\mathrm{a}}$ & $10^{a}$ & $4^{a}$ & $6^{a}$ & $3^{a}$ \\
\hline Child disorders & $7^{a}$ & $7^{a}$ & $10^{\mathrm{a}}$ & $4^{a}$ & $11^{a}$ & $2^{a}$ & $3^{a}$ & $10^{\mathrm{a}}$ & $10^{\mathrm{a}}$ & $4^{a}$ & $6^{a}$ & $2^{a}$ \\
\hline
\end{tabular}




\begin{tabular}{|c|c|c|c|c|c|c|c|c|c|c|c|c|}
\hline Conduct disorder & $5^{a}$ & $6^{a}$ & $4^{a}$ & $7^{\mathrm{a}}$ & $11^{\mathrm{a}}$ & $0^{\mathrm{b}}$ & $1^{\mathrm{a}}$ & $10^{\mathrm{a}}$ & $11^{a}$ & $0^{b}$ & $7^{a}$ & $1^{a}$ \\
\hline $\begin{array}{l}\text { Neuroleptic } \\
\text { Malignant } \\
\text { Syndrome }\end{array}$ & $7^{a}$ & $5^{a}$ & $8^{a}$ & $4^{\mathrm{a}}$ & $5^{a}$ & $4^{\mathrm{a}}$ & $0^{\mathrm{a}}$ & $12^{b}$ & $5^{a}$ & $7^{a}$ & $6^{a}$ & $4^{a}$ \\
\hline OCD & $7^{a}$ & $3^{a}$ & $7^{a}$ & $3^{a}$ & $5^{a}$ & $4^{\mathrm{a}}$ & $4^{a}$ & $5^{a}$ & $5^{a}$ & $5^{a}$ & $4^{a}$ & $6^{a}$ \\
\hline $\begin{array}{l}\text { Autism spectrum } \\
\text { disorder }\end{array}$ & $1^{\mathrm{a}}$ & $5^{a}$ & $4^{a}$ & $2^{a}$ & $4^{a}$ & $0^{\mathrm{a}}$ & $1^{\mathrm{a}}$ & $4^{a}$ & $4^{a}$ & $2^{a}$ & $6^{a}$ & $0^{\mathrm{b}}$ \\
\hline ADHD & $1^{\mathrm{a}}$ & $3^{a}$ & $1^{\mathrm{a}}$ & $3^{a}$ & $4^{\mathrm{a}}$ & $0^{\mathrm{a}}$ & $0^{a}$ & $4^{a}$ & $4^{a}$ & $0^{b}$ & $3^{a}$ & $0^{a}$ \\
\hline Other diagnosis & $25^{a}$ & $13^{\mathrm{a}}$ & $24^{a}$ & $14^{\mathrm{a}}$ & $26^{a}$ & $8^{a}$ & $6^{a}$ & $29^{a}$ & $20^{a}$ & $18^{a}$ & $18^{a}$ & $14^{a}$ \\
\hline Total & 2001 & 1725 & 2375 & 1351 & 2468 & 925 & 1091 & 2421 & 1788 & 1931 & 1891 & 1427 \\
\hline $\mathrm{X}^{2}$ & 448,831 & & 76,155 & & 158,0 & & 155,1 & & 515,8 & & 153,1 & \\
\hline p & $\leq 0.001^{*}$ & & $\leq 0.001^{\star}$ & & $\leq 0.00$ & & $\leq 0.00$ & & $\leq 0.00$ & & $\leq 0.00$ & \\
\hline
\end{tabular}

* Statistically significant difference at a significance level of $5 \%$.

a,b Different letters denote a statistically significant difference.

Table 3. Study of the association between the requesting area and non-assessment.

\begin{tabular}{|c|c|c|c|c|c|c|}
\hline \multirow[b]{2}{*}{ Consultation-liaison psychiatry } & \multicolumn{6}{|c|}{ Requesting Area } \\
\hline & Emergency & Ward & ICU & Total & $x^{2}$ & $\mathbf{p}$ \\
\hline Yes & $883^{a}$ & $1.498^{\mathrm{a}}$ & $154^{\mathrm{b}}$ & 2.535 & $21,347^{a}$ & $<0,001^{*}$ \\
\hline Not evaluated & $66^{a}$ & $98^{\mathrm{a}}$ & $28^{b}$ & 192 & & \\
\hline Total & 949 & 1.596 & 182 & 2.727 & & \\
\hline Reason of non-assesment & Emergency & Ward & $\mathrm{ICl}$ & Total & $x^{2}$ & $\mathrm{p}$ \\
\hline Hospital discharge & $20^{a}$ & $27^{a}$ & $1^{\mathrm{b}}$ & 48 & 55,230 & $\leq 0,001^{*}$ \\
\hline Absent (laboratory test, procedures) & $3^{a}$ & $20^{\mathrm{b}}$ & $3^{a, b}$ & 26 & & \\
\hline Hospital evasion & $10^{\mathrm{a}}$ & $5 b$ & $0^{\mathrm{b}}$ & 15 & & \\
\hline Impossibility to respond (coma, intubation) & $5^{a}$ & $5^{a}$ & $13^{\mathrm{b}}$ & 23 & & \\
\hline Inability to respond & $18^{a}$ & $21^{\mathrm{a}}$ & $6^{a}$ & 45 & & \\
\hline Outro & $10^{\mathrm{a}}$ & $20^{\mathrm{a}}$ & $5^{a}$ & 35 & & \\
\hline Total & 66 & 98 & 28 & 192 & & \\
\hline
\end{tabular}

* Statistically significant difference at a significance level of $5 \%$.

a,b Different letters denote a statistically significant difference.

\section{Figures}




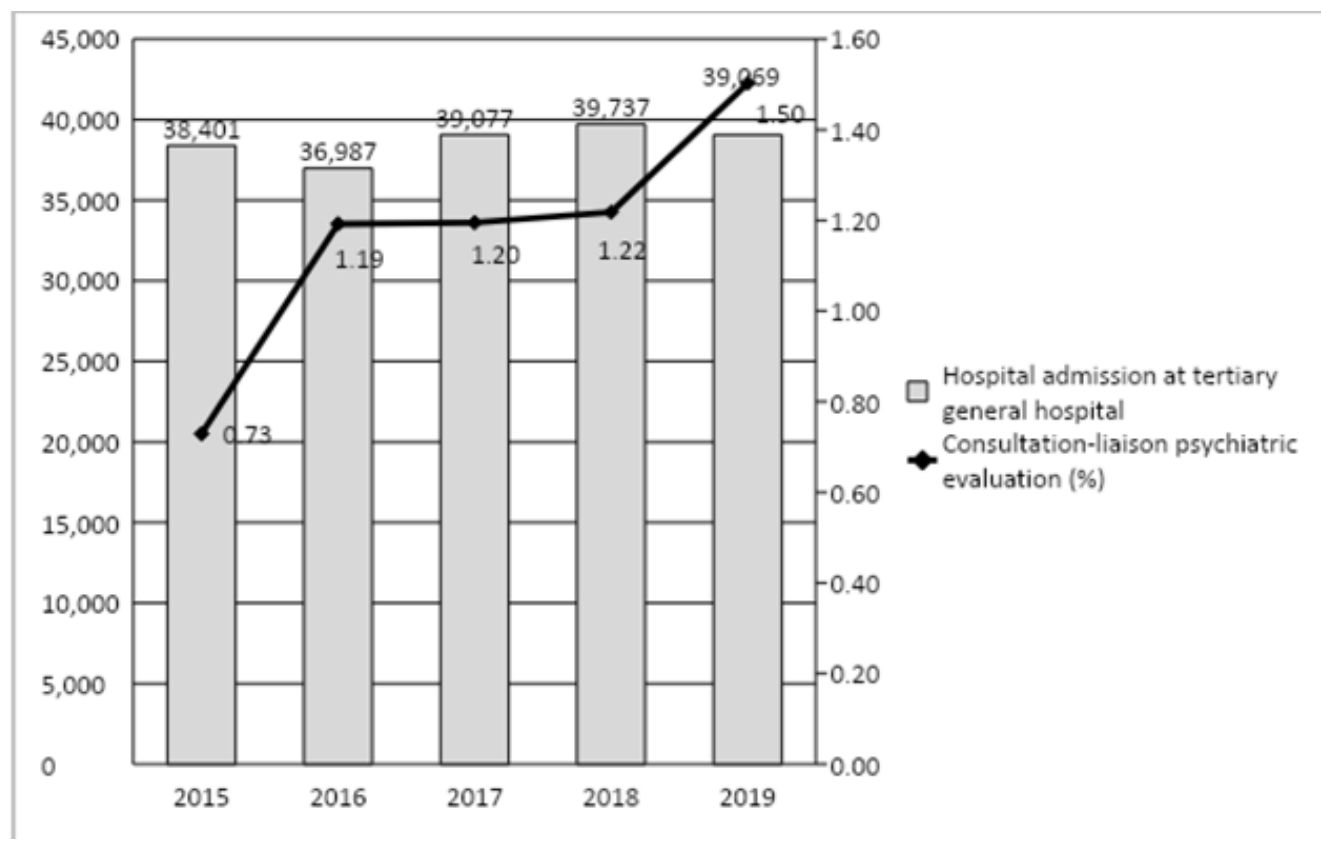

\section{Figure 1}

Number of admissions made at Hospital de Base and percentage corresponding to the number of psychiatric evaluations considering the years 2015-2019. 